\title{
Colonial Homelessness
}

Christine McCarthy, Interior Architecture, School of Architecture, Victoria University

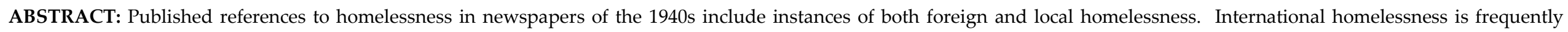

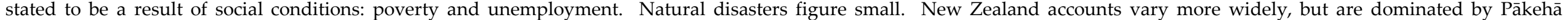

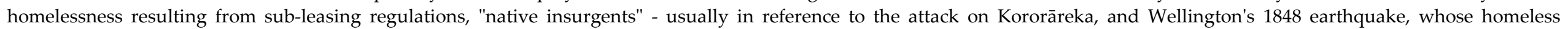

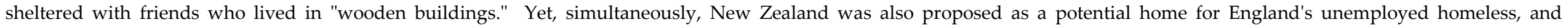

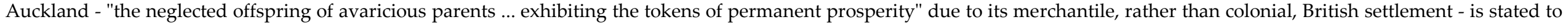

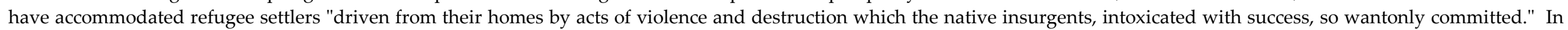
1840s newspapers there are no references to homelessness in serialised literature, and few abstract uses of the term.

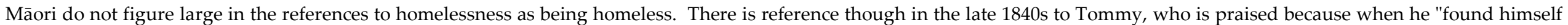

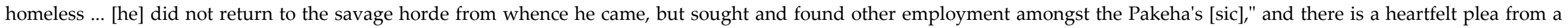

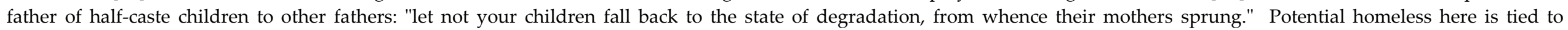

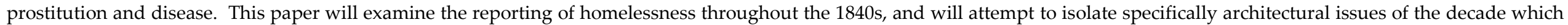
emerge from this.

\section{Introduction}

Homelessness is an increasing issue in New Zealand cities. Just as I am writing this Radio New Zealand are bringing the Hamilton City Council to task for introducing a by-law criminalising "homelessness."1 Recently Wellington's mayor (Celia Wade-Brown) and ten council staff slept "rough" for a night to acknowledge World Homeless Day on Friday 10 October. $^{2}$ The visibility of homelessness is increasing - some would say because of failed social welfare infrastructure and support, but it is a topic that architecture schools often

\footnotetext{
1 "Hamilton plan to ban rough sleeping" n.p.

2 "Mayor and WCC Staff Temporarily Homeless" n.p.
}

ignore, exceptions including Texas Tech's Lubbock Homeless Facility ${ }^{3}$ and the University of Oregon architecture students. ${ }^{4}$

Homelessness and related debates appear to have a long history in New Zealand, and this paper examines homelessness in the 1840s via New Zealand English-language newspapers published in the $1840 \mathrm{~s} .{ }^{5}$ This material

\footnotetext{
3 "Architecture Faculty, Students Help Develop Lubbock Homeless Facility" n.p.

${ }^{4}$ University of Oregon "UO architecture students work together to tackle homelessness" n.p.

${ }^{5}$ The papers which refer to homelessness (and

houselessness) are: The New Zealand Gazette and

Wellington Spectator (1840-44), the Nelson Examiner and
}

New Zealand Chronicle (1842-49), the Daily Southern Cross (1843-49), the New Zealand Spectator and Cook's Strait Guardian (1844-49), the New Zealander (1845-49), and the Wellington Independent (1845-49). Such papers were weekly (or occasionally fortnightly), with publication frequency increasing in steps to bi- and tri-weekly editions. For example, it wasn't until 1861, when the Otago Daily Times was published, that New Zealand got its first daily newspaper (Jackson and McRobie, Historical Dictionary of New Zealand p 5). Other 1840s New Zealand newspapers digitised on Papers Past include: the short-lived New Zealand Advertiser and Bay of Islands Gazette (1840), the New Zealand Colonist and Port Nicholson Advertiser (1842-43), and the Victoria Times (1841), which only had one issue. The research also omits papers yet to be digitised, including: the New Zealand Herald and Auckland Gazette (1841-), Auckland Chronicle and the New Zealand Colonist (1841-), the 
identifies 1844 as the year when the first idea of New Zealand homelessness occurred, and indicates a distinction between New Zealand and English homelessness. England contextualises the emergence of homelessness in New Zealand, suggesting that homelessness is an imported idea. English houselessness was also stated as a rationale for (or perhaps a positive byproduct of) the colonial project. In the newspapers, English houselessness is quantified, and linked to poverty and welfare need, both New Zealand and English homelessness is imagined in literary explorations, and a geographical breadth (beyond that of New Zealand and Britain), is represented in the reporting of homelessness in relation to natural disasters.

In contrast to English homelessness, New Zealand homelessness is seen to be largely political, resulting from the incompetence of the New Zealand colonial government. This is with respect to the colonial government's relationship with Māori, and with respect to regulations and practices pertaining to land, in particular leaseholds, and government land control. The source material also indicates distinct meanings for houselessness and

Auckland Times (1842-), the Island Bay Observer (1842-). homelessness, and draws from a range of different literary forms, namely: editorials, reprinted articles, articles, letters to the editor, overseas serialised novels, overseas and New Zealand poetry.

As well as the conventions associated with each of these forms of writing, the colonial newspaper itself is an inherently-biased literary medium. For example, the New Zealand Company, responsible for much Pākehā settlement, founded and provided funds for a number of local papers demonstrating explicit connections between colonial politics and the colony's early press. NZ Company newspapers, namely the New Zealand Gazette, and the Nelson Examiner, contribute $37 \%$ of the source material. Such financial support was necessary as newspapers in 1841 appear to have been expensive endeavours. Patrick Day points to the New Zealand press as reflecting the class structure of colonial New Zealand and being

restricted to the more wealthy settlers purely by their cost. The price of the New Zealand newspapers before the advent of the penny press was high. ${ }^{6}$

A single issue of a newspaper typically cost in

${ }^{6}$ Day The making of the New Zealand Press p 68. the region of one shilling in the early 1840s, about half that in the late 1840s. Day suggests that the readership of the newspapers were the middle- and upper-classes, calculating that:

[a]n annual subscription to a newspaper ... would represent from one to two weeks wages for a tradesman and the money that a domestic would receive over approximately six weeks ... price alone was sufficient to prevent the majority of settlers from being newspaper subscribers. ${ }^{7}$

This confined readership no doubt impacted on the number and type of stories about homelessness present in newspapers.

\section{The homelessness of "Home"}

The first mentions of homelessness in New Zealand newspapers (beginning from July 1842 until June 1844) are not of homelessness in New Zealand. Instead homelessness is often termed "houselessness," and is very much confined to Britain. It is an imported idea. A reprinted excerpt from Glasgow Paper in December 1841 contains the first reference

${ }^{7}$ Day The making of the New Zealand Press p 69; "[1846] Domestic, per annum with board and lodging, $£ 14$ to $£ 20$ : Predial, per annum with board and lodging, £25 to $£ 45$ : Trades, per diem, $5 \mathrm{~s}$ to $7 \mathrm{~s}, "$ cited in Day The making of the New Zealand Press p 68 
to houselessness, and it states that 555 people used the Night Aslyum for the Houseless in St. Enoch's Wynd, Dundee during the last week of December. ${ }^{8}$

This type of statistical reporting is echoed in an April 1844 article about the seasonal opening of the Refuge for the Houseless in Playhouse yard, Whitecross Street, which had 246 admissions of homeless people over the first four days of the week. The text notes that "[e]ach person admitted has a compartment of straw, 18 inches wide, which is cleansed twice each week,"9 suggesting the accommodation of animals rather than people, ${ }^{10}$ with 18 inches pailing in comparison to the 36 inch width of an English single bed today. Two months later, another article, described the widespread adoption of "nightly houses of refuge for the destitute" throughout Britain,

8 "New Zealand Gazette and Wellington Spectator" p 3. The night asylum was a recent addition to that town's architecture, having opened on 28 May 1838 as "The Night Asylum for the Houseless" and, in 1842, a "House of Industry for Indigent Females" was added. By 1847 more accommodation was needed for Dundee's

homeless and a new building opened then in North Frederick St. ("Night Asylum for the Houseless" n.p. 9 "English Extracts" (6 April 1844) p 19.

${ }^{10}$ Straw mattresses were used into the nineteenthcentury, but usually under a woolen or feather mattress. following London's example, as well as landlords reducing rent due to tenants' hardship. ${ }^{11}$ The reporting of houseless statistics was seen again in September 1847, when the Nelson Examiner reported that:

[u]pwards of 50,000 persons are stated to be inmates of the London workhouses, 60,000 receiving out door relief, and from 1400 to 2000 nightly sheltered in refuges for the houseless. ${ }^{12}$

In the same month, the Wellington Independent referred to a House of Commons' report documenting that "19,000 received nightly relief from the various different charitable institutions for the receptions of the homeless and destitute." 13 These numbers must have struck many New Zealanders as immense. While the population of England in 1851 was over 15 million $(15,288,855)$, the New Zealand Pākehā population in 1851 is estimated to have been in the realm of $27,000(26,707) \cdot{ }^{14}$ The Māori population was greater than the Pākehā population - suggesting a New Zealand population of over 60,000 - but, even then, presumeably the figure of 60,000

\footnotetext{
11 "Latest English Intelligence" p 60.

12 "Scraps of English News" p 106. See also: "Nelson" p 2. and "Latest News" p 3.

13 "English Intelligence" p 3.

14 "Demography of England" n.p.; "Population" n.p.
}

homeless in London alone, must have conveyed the magnitude of difference between England and New Zealand, and perceptively supported Pākehā notions of New Zealand as under-populated and accommodating.

The reporting on English/British homelessness was persistent throughout the 1840s, and followed this interchange between the highly specific, such as this accounting of homelessness, and generic rendering. Published accounts related homelessness to deficient dwelling, destitution and hardship and the nocturnal (i.e. night shelters). The use of architectural terms such as asylum, refuge and shelter, along with the detail of compartments of straw, indicate a barely sufficient and minimal accommodation in contrast to contemporary notions of house and home. Houselessness was associated with possession-less vagrancy, exampled in one 1845 account of London at midnight attributing "personal liberty" as the single remaining possession of "the houseless wanderer," 15 while another from the same year warned about "those who are homeless by choice," concluding that "Vagabond and

\footnotetext{
15 "Art and Literature" p 4.
} 
rogue are convertible terms."16 Mobility is both a symptom of houselessness, but also the mechanism to effect the colonial project which can transplant the British unemployed homeless to full employment and housing in the colonies. One editorial, for example, referred to "poverty and starvation of the British massess" as "befriend[ing] the colonies."17 Another article titled: "The Rage for Emigration, and the causes of it," describes the numbers of British destitute where:

numbers exist in indigence; numbers live in workhouses and prisons; numbers without a home, sleep houseless on the seats of her parks, and rise from their cold beds penniless and breadless; numbers work hard, live poor, dress ragged, appear emaciated; and die miserable. ${ }^{18}$

The revolting French were held up as a warning for the English, in part contextualised by the contemporary humanitarian disaster in Ireland, but largely to depict the unemployed homeless as a poltical timebomb: ${ }^{19}$

There are in this United Kingdom some millions who possess neither property, nor comfortable tenure, nor regular employment sufficient for a decent existence. ...

\footnotetext{
16 "Electricity Applied to Agriculture" p 4.

17 "The New Zealander" p 2.

18 "The Rage for Emigration" p 5.

${ }^{19}$ The effects of the potato famine were graphically described in "Ireland: State of the West" $\mathrm{p} 4$.
}

These men, as a body, will be revolutionists in one form or another. ... they only want a system which will feed, and clothe, and house them better. ... in our colonies we possess the means of employing any excess of population. ... It is no longer a question whether emigration should be encouraged. Emigration is now indisputably shown to be the great outlet for these islands. ... We cannot wait till the tedious processes of the law have divided Irish properties. ${ }^{20}$

Colonial migration is also explicitly referred to in the work of migrant English poet Robert Croudace Joplin (1822-1907), ${ }^{21}$ who wrote New Zealand: a poem in 1843.22 Croudace had established a school in Auckland in 1843, ${ }^{23}$ and would later become a bank manager in Australia. ${ }^{24}$ His 1846 "New Zealand, As It Is" articulated the contrasts in prosperity between England and New Zealand, and confirms the colonial rhetoric of New Zealand as panacea to England's social ills. The poem begins stating that early New Zealand immigrants worked hard, without comfort, for little money, but now:

That hour is past ... those, whose industry Could barely feed before,

\footnotetext{
20 "English Extracts" (16 September 1848) p 115.

21 "Obituary" p 3.

22 Joplin New Zealand: a poem

23 "New School [advertisement]" p 2.

24 "Obituary" p 3.
}

For every shilling they made then,

Now earn a pound, or more!

This prosperous situation is contrasted with the "many hungered families, /[who] In England curse their doom!" He calls on England's rulers to "Leave not the gaunt and houseless wretch,/ To perish at your door!"

Houselessness is hence associated with hunger, physical bodily decline, and death. The poem continues arguing that instead of accommodating the houseless in England, politicans ought to

send him HERE, and he will soon

Be housed, and clothed, and fed

Ours is a healthy clime, and we

Can well afford him bread.

Houselessness is hence associated with England, while New Zealand is connected to the relief and resolution of houselessness. The persistent use of houselessness, rather than homelessness, perhaps avoids potential irreconciliation with notions of England as "Home," while Croudace's use of "ours" and "we" suggests a fast adoption of his new home. Directly addressing England's rulers, these appear to be founded on an assumption that the houseless are dispossessed of agency 
and franchise.

In a similar vein "A landpurchaser and farmer" observed that "[w]hile in England, tens of thousands are langishing for want of employ, here, at the other extremity of the empire, business is stagnating for want of labour;"25 the letterwriter urging that the newly arrived emigrants are offered "the utmost possible facilities for the present rental, and ultimate purchase, of a few acres of land" to prevent their leaving Nelson for other parts of the colony, so that they "become fixed and permanent members of the community, instead of mere homeless wandered, ever in quest of the colony promising (often delusively) the most immediate advantages in the shape of high wages." 26

The desire for the security and comfort represented by having a "home," is similarly stated in the only South African reference, which is a letter from the governor, HG Smith, and refers to the re-establishment of domestic security to justify his proclaiming the territory beyond the Orange River as under the

${ }^{25} \mathrm{~A}$ land purchaser and farmer "Correspondence" $\mathrm{p} 37$. ${ }^{26} \mathrm{~A}$ land purchaser and farmer "Correspondence" $\mathrm{p} 37$.

\section{Sovereignty of her Majesty:}

What have I done for your countrymen in Natal - part of her Majesty's dominions? I found them wandering they knew not whither, from their homes ... I took such steps as to ensure their return to their comfortable homes and I appointed the man who has great influence with you one of a land commission, the result of the labors of which would ensure the great point - undisputed right of possession of your land. ${ }^{27}$

\section{Fictional/literary homelessness}

The link of mobility and homelessness is strengthened in literary accounts. Many of these are serial installments, excerpts of novels or poems, while literary allusion also occurs. Reference to the literary character Sam Slick from Thomas Chandler Haliburton's 1836-40 satire: The Clockmaker, or the Sayings and Doings of Samuel Slick of Slicksville linked homelessness to restlessness, rather than poverty, in a reference to:

Vagrant Sam Slicks, who rove over the Earth doing "strokes of trade" ... Slick rests nowhere, he is homeless. He can build stone or marble houses; but to continue in them is denied him. ${ }^{28}$

Here the inability to dwell in a building is

27 "Cape of Good Hope p 1.

28 "The Nelson Examiner" (18 November 1843) p 354; also "Re-Emigration" p 3 coincident in the "houseless" and the "homeless." Rather than migrancy, a move to another place, Slick, the travelling salesman, does not stop; he is seemingly unable to achieve a destination or any notion of settlement.

Mobility also underpins a published excerpt from Dickens' travelogue American Notes for General Circulation, ${ }^{29}$ which admired the affection apparent among homeless English and Irish emigrant families newly arrived to Canada and pondered the difficulty of being virtuous for the poor, in contrast to the rich. ${ }^{30}$ Dickens' text is contextualised by a later report, reprinted from The Times, which described Irish migration to Canada as a slave-trade. It stated approximately 100,000 as the seasonal number of people migrating, with $18 \%$ dying, and $19 \%$ ill on arrival, but anticipated houselessness as a larger problem, stating "Who can say how many will perish on the way, or the masses of houseless, famished and half-naked wretches, that will be strewed on the inhospitable snow when a Canadian

${ }^{29}$ American Notes for General Circulation was published in New Zealand in November 1843, just over a year after it was published in London.

30 "Miscellaneous" (8 November 1843) p 3; Dickens American Notes for General Circulation pp 204-206. 
winter once sets in?"31 Another article graphically rendered the impact of the potato famine, suggesting that even the depicted horror of migration to Canada did not compare with the magnitude of Ireland's misfortunes:

the bodies of human beings half buried along the road sides, in the fields, and in the bogs; the peasants unable to walk from the effects of sheer starvation; and a total disappearance of cultivation. ... Men who, but a few short years ago, were the comfortable owners of half a dozen cows, thirty or forty sheep, and a good strip of mountain ground to sustain them - men who lived decently, and carried on a continual exchange of one article of food for another, living after their own rude fashion, are now the poorest of God's suffering creatures, stalking through the country, hungry, naked, and homeless, and wishing for death, as a happy termination of their sufferings. ... those who have just sufficient to remove them from the sight of such misery hasten to get a glimpse of that promised land, where to be industrious is a blessing, and where people are now finding a new home. ${ }^{32}$

Dickens' class contrast in American Notes links homelessness to the realities of poverty, a correspondence not always simply or comprehensively made; the references to Slick's vagrancy, for example suggesting a restlessness less immediately connected with

\footnotetext{
31 "The Canadian Ship-Fever" p 3

32 "Ireland: State of the West" p 4.
}

his occupation as an itinerant salesman.

A second Dickens' excerpt about homelessness was published in 1847.33 This was an installment of Dombey and Son, which was serialised from 1846, and published as a novel in 1848. Homelessness here is attributed to an inanimate - but seemingless traumatised - object, a hearth rug in a secondhand furniture shop, whose wares were animated and personified. Their forms become bodies variously comprising: shoulders, legs, a bosom, a brain and a finger. They stand, belong, tremble and complain, among the genial company of other household furnishings, seemingly cognisant of but incapable of normative social custom. The homeless hearth-rug is comprehensively described:

severed from its natural companion, the fireside, [having] braved the shrewd east wind in its adversity, and trembled in melancholy accord with the shrill complaining of a cabinet piano, wasting away, a string a day, and faintly resounding to the noises of the street in its jangling and distracted brain. ${ }^{34}$

It is socially disconnected (from its natural companion), subject to the harshness of the

33 "Miscellaneous" (19 May 1847) p 2.

34 "Miscellaneous" (19 May 1847) p 2. environment (the shrewd east wind), traumatised (trembled in melancholy), and in accord with the piano which experiences bodily decline (wasting away, a string a day), and mental disturbance (its jangling and distracted brain). While it is the piano who is mentally disturbed, rather than the homeless hearth-rug, the rug is socially deprived/inept and emotionally disturbed, extending the breadth of homelessness beyond that of houselessness, or rather as distinct from houselessness.

Ellison relates Dickens' descriptions of the interior in Dombey and Son as susceptible to the capitalist impetus to mobility noting that:

Mobilized interiors composed of goods purchased, moved, renovated, seized, or evacuated appear as one of the critical shocks that Dombey and Son explores in its depiction of volatile dwellings. Homes are repeatedly opened up by and to external forces - death, bankruptcy, matrimony, and its dissolution - that set things in motion. ${ }^{35}$

This trauma is not a displacement from building but rather a displacement from a stable notion of domesticity affected by social relations, social status and socially sanctioned

${ }^{35}$ Ellison "Mobile homes, Fallen Furniture" p 91 (emphasis added). 
behaviour/moral compass/morality. Ellison observes that Dickens' description of Brogley's goods, the context of the homeless hearth rug:

converts them into lively subjects within the space of a single paragraph. Their posture, animated by micronarratives of fallenness, charts the movement from uprightness to an eroticized sprawl that is Hogarthian in shape. Theirs is a familiar progress: beauty lured and mired ... souring into the inevitable dissolution of home ... body ... and finally mind .... Unlike Hogarth, where disordered furniture analogizes the harlot's condition, Dickens's treatment reverses the terms. Sexual fall tells us something about furniture-not simply that the domestic is a feminized domain, but that its constituent elements are already tracing a feminine narrative arc Their return to the street matches a path encoded in emergent middle-class anxieties, not just in the prospect of fall, but also in the interchangeability of "good" and "bad" women and in the possibility that prostitution might be a stage in the ascension toward respectability. Dickens establishes a situational affinity. Like the bride with a secret (or syphilitic) past, furnishings are of uncertain legitimacy and as such endanger the meaningful division of space. Fallenness is an in-built condition, a hidden spring resident in objects that can revert to exchangeability - whether a chair or a woman or, for that matter, a woman in a chair. ${ }^{36}$

The conflicting Victorian narrative of prostitution, the "interchangeability of "good" and "bad" women" apparent in Dickens' novel also surfaces in Thomas Hood's, now famous,

${ }^{36}$ Ellison "Mobile homes, Fallen Furniture" p 96. poem "Bridge of Sighs" (1844), which personifies "the legion of anonymous London prostitutes who drowned themselves each year," ${ }^{37}$ and which

became a Victorian catchphrase, succinctly expressing the prevalent, sentimentalized view that suicide by drowning constituted an act of spiritual and social atonement for "fallen" women. ${ }^{38}$

The poem describes the retrieval of the young (homeless) prostitute's body as now "past all dishonor,/ Death has set on her/ Only the beautiful." The poem asks "Where was her home?," and describes her as "Houseless by night," and attributes this to insufficient charity:

Alas, for the rarity

Of Christian charity

under the sun!

$\mathrm{O}$, it was pitiful

Near a whole city full,

Home she had none. ${ }^{39}$

These literary articulations of poetry, which depict the socially unstable and welfare deficient England, reinforce the reportage contrasting English and New Zealand, and

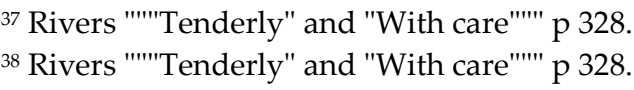

${ }^{39}$ Hood "The Bridge of Sighs" p 4. establish associations and metaphoric meanings of homelessness within New Zealand print, but 1840s New Zealand as prosperous and accommodating. England, in particular, is a place of upheaval and social problems. These associative and connotative meanings include poverty and virtue, the poor as morally instructive, disorder and upheaval, homelessness as a result of economic capitalism, the homeless as "fallen."

The Victorian anxiety with prostitution, or rather the socio-cultural investment in retifying the morally compromised, apparent in Hood's poem, was also played out as a cross-cultural dilemma in the idea of halfcaste children in New Zealand. An October 1847 letter to the editor compressed western assumptions about a hierarchy of race, progress and civilisation, and genetic inevitability - articulated through the complexities of paternalistic devotion - in a pleading from the self-described father of half-caste children to other fathers:

It makes my blood boil with indignation, when I see the friendless, homeless, daughters of Europeans, by native women, with their delicate and interesting features and persons, wandering about, the victims of prostitution 
and disease..$^{40}$

A direct connection between Māori and homelessness is rare, and in addition to concern for homeless half-caste daughters, the account of Tommy who became homeless after losing his job is unusual. The racism, however, is explicit with reporting that patronises Tommy into caricature:

When Tommy found himself homeless, he did not return to the savage horde from whence he came, but sought and found other employment amongst the Pakeha's[sic], where he is respected as a faithful and trusty domestic. Tommy is a lover of a drop of grog, yet he seldom takes it to excess. ${ }^{41}$

\section{Bureaucratic incompetence and regulatory unfairness}

The theme connecting British homeless to New Zealand and the colonial project is also considered through a lens of political incompetence. An 1843 column, for example states that "New Zealand is as much a part of England, as the Isle of Wight, and, under decent management, might offer a home to hundreds, who are homeless, and a market for

\footnotetext{
${ }^{40}$ A father of Half-Caste Children "Original

Correspondene [sic]" p 3.

${ }^{41}$ Subscriber (18 February 1848, Porirua) "Original
} Correspondence" p 3 . thousands now unemployed." 42 The reference is contextualised within a detailed criticism of Hobson's financial management of $\mathrm{New}$ Zealand, which highlights Hobson's revenue gathering and spending priorities as askew: "He has a knack of beginning at the wrong end. Thus, in his account of expenditure, he puts down $£ 7,957$ for Police and Gaols, and $£ 140$ for Schools!" The article describes New Zealand as

an island, where there were no antiquated abuses to deal with, - no adverse interests to conciliate, - no corrupt habits to provide against, - but where everything encouraged the application of the simplest principles to a virgin soil. 43

This Arcadian image of New Zealand, criticised in Mark Wigley's "Paradise Lost and Found," was easily perpetrated as a contrast to England's declining social infrastructure. England had "no uniform national welfare system," 44 and following the 1834 Poor Law, which reduced eligibility and consequently reduced welfare costs in a system designed "to enforce a flexible labour market ... and .... an economcially and morally "independent" (i.e.

\footnotetext{
42 "English Extracts" (6 May 1843) p 3.

43 "English Extracts" (6 May 1843) p 3

${ }^{44}$ Wigley "Paradise Lost and Found" pp 44-45; Kidd "The "Liberal State"'" p 116.
}

self-reliant) people,"45 England experienced "a pattern of declining state welfare provision dating from the 1830s."46 This contrasted the poor relief previously available in England in the late eighteenth and early nineteenth centuries. Kidd states that:

[t]he level of per-capita expenditure on poor relief reached between 1813 and 1822 and in the early 1830s was not to return until the 1920s when the use of poor relief to deal with the mass unemployment of the interwar years caused a rapid escalation in costs. In between these twin peaks the average per capita cost during the Victorian era was less than half the figures for the second decade of the nineteenth century. ${ }^{47}$

Kidd also observes that "A theoretical division of labour developed, whereby charity dealt with the deserving and the Poor Law offered a safety net for the rest (the destitute)."48 This class stratification of the poor into the deserving and the destitute supplements Wakefield's ambition to make New Zealand "a transplanted pre-industrial English class structure."49 As Smith notes: "Nearly 10,000 settlers migrated under company schemes in the 1840s, carrying with them hopes of a

\footnotetext{
${ }^{45}$ Kidd "The "Liberal State"'" p 117.

${ }^{46}$ Kidd "The "Liberal State"'" p 116 (emphasis in original)

${ }^{47}$ Kidd "The "Liberal State"'" p 117.

${ }^{48}$ Kidd "The "Liberal State"'" p 118.

${ }^{49}$ Smith A Concise History of New Zealand p 44.
} 
better life."50 New Zealand is hence contrasted with the Old World, and figured as an appendage able to resolve England's social problems. Thomson argues that New Zealand was envisaged by the colonial settlers as a world without welfare, and a world without the English poorhouse, ${ }^{51}$ which was the subject of many New Zealand-published references to homelessness, which perhaps worked initially perpetrating this belief that New Zealand would be different to England, and would not need the poorhouse.

\section{New Zealand-specific homelessness}

1844 is the first reference to New Zealandspecific homelessness. It is a generic reference related to the ramifications of a specific regulation, rather than a material and particular instance of homelessness. It is also the first "Letter to the Editor" to raise issues of homelessness. The author of the letter, "A Sub-Tenant," contrasts New Zealand and English practises of sub-letting, observing, of the sub-tenant, that "the fruits of his labour after years of toil," clearing the land, planting cropping and building a house, are insecure, because sub-tenants are liable for the lessee

${ }^{50}$ Smith A Concise History of New Zealand p 59.

${ }^{51}$ Poirer Charity Law in New Zealand p 88. rents due to the landowner, and because:

To-morrow it may be they will have to leave their house and their cleared land the work of years, crop and other property every penny-worth ... victims of legal robbery, homeless and pennyless ... and take another sub-lease of some monopolist lessee, and live on cabbage-tree, or air or charity until they shall have in the course of another two or three years retrieved their now truly bankrupt condition by farming another settlement to be come in its turn the subject of distress for arrears of rent not their own. ${ }^{52}$

The writer concludes that sub-tenants will "have toiled in vain for themselves, [but will] have at least been useful to the colony." 53 The point appears to be that a law which works in England, as a developed western country, did not work in New Zealand's pioneer condition. The work required to make New Zealand habitable - in English eyes - is needed in order to live, but the capital gains are unable to acrue to the sub-tenant, who, in contrast to their English equivalent, must invest money and labour to the benefit of the landowner while the sub-tenant is vulnerable to homelessness and poverty.

${ }^{52}$ A Sub-Tenant (28 June 1844) "To the Editor of the New Zealand Gazette and Wellington Spectator" p 3.

${ }^{53}$ A Sub-Tenant (28 June 1844) "To the Editor of the New Zealand Gazette and Wellington Spectator" p 3.
While 1844 was the first articulation that New Zealand homelessness was possible, 1845 is a pivotal year in the Pākehā comprehension of potentially widespread Pākehā homelessness in New Zealand. In this year the first case of Middleton, a specific man's homelessness, is documented (and disputed), and the "sacking of Kororareka," which traumatised many North Island Pākehā, occurred. In contrast to the events of 13 June 1843 at Wairau, which do not appear in the homeless reportage, Kororāreka resulted in the reported displacement of homeless Pākehā from Kororāreka to Tāmaki Makaurau/Auckland.

The story of Middleton permeated numerous letters to the Editor in the Nelson Examiner. Middleton, who had become homeless due to rent arrears, was arrested for squatting on a government reserve, while other squatters remained "unmolested." 54 The Nelson letter writer ("S.T.") describes Middleton's treatment as a "wanton outrage." The letter created a longer discussion about squatting in the town belt in nine replies, which included a second "S.T." letter. ${ }^{55}$

${ }^{54}$ S.T. "[Letter to the Editor]" "Correspondence." p 206 ${ }^{55}$ S.T. "To the Editor of the Nelson Examiner" p 7. 
The newspaper accounts of the events at Kororāreka, with respect to homelessness, commence in late March, beginning with the Daily Southern Cross. It stated that:

the oldest settlement in New Zealand has been laid in ashes, its inhabitants expelled and dispersed, - some, after having spent half a life-time in it, houseless, homeless, pennyless, and irretrievably ruined. ${ }^{56}$

Homelessness slips in amongst political satire, in an oblique reference to Kororāreka, repeating previous opinion that the Chief Protector's inamoured view of Māori has blindsighted him: "Rebellion, fire, blood, the ashes of a smouldering city, the cries of the hungry houseless, greet his astonished senses." ${ }^{27}$ In a similar way, the Wellington Independent noted that the "Bay of Islands had been reduced to ashes by his Excellency's friends," 58 as it concludes that if the Governor had supported Lord Stanley's Militia Bill:

the Bay of Islands would still have been a flourishing settlement. Hundreds would not now have been houseless wanderers ... Lord Stanley ordered a Militia Bill to be passed on the 11th March, 1844, and on the 11th March 1845, Kororarika was a heap of ashes, because Captain Fitzroy had refused to obey his

\footnotetext{
56 "On Recent Events" p 2.

57 "The Nelson Examiner" (10 May 1845) p 38.

58 "Wellington Independent" p 2.
}

instructions. ${ }^{59}$

Reference to the homeless continues until July 1845, but moves from the Auckland Daily Southern Cross to Nelson (The Nelson Examiner) and Wellington (Wellington Independent) with one mention in the New Zealander (Auckland). The focus largely excludes discussion or reporting of the event - perhaps because this was done extensively elsewhere. Instead the topic of hundreds of refugees from the north, "compelled to leave their homes"60 arriving in Auckland becomes a concern, and a shift from the political context which caused the northern wars to the political need to address the homeless status of these "refugees" is voiced, to the disadvantage of Wellington's New Zealand Company:

We know not the views or intentions of the Local Government towards the very numerous pursuits, now congregated in Auckland; but we would suggest that they should immediately have land allotted to them, so that they may erect dwellings, and in some degree obtain a subsistance by raising food. ... Indeed, we see no reason why the Government should not resume possession of the town [Auckland] and suburban allotments set apart for, but not yet purchased by, the New Zealand Company. They will never be taken possession of by settlers sent out by that Company, and

59 "Wellington Independent" p 2.

60 "Refugees from the Bay of Islands" p 3. reserving them, only prevents the occupation and improvement of the town and neighbourhood ... it would induce many of these houseless fugitives to remain here, instead of leaving the Colony - and that they would receive great and liberal assistance, in various ways, for their dwellings and cultivation, from the residents of Auckland and neighbourhood. ${ }^{61}$

\section{Natural Disasters}

While the most frequent discussion of homelessness in New Zealand newspapers is focussed on England and New Zealand, the homelessness of other geographic regions emerges, primarily with respect to the consequences of natural disasters (including fires). The first of these reported was a fire in Quebec in 1845, one of a number that year. The report stated 20,000 people were houseless, and the Parliament had commenced a fund with $£ 20,000$ in anticipation of public subscriptions. ${ }^{62}$ The fire in St John's Newfoundland in June 1846 caused an estimated 6,000-7,000 houseless, mainly women and children, the men having literally gone fishing. ${ }^{63}$ The report appeals to "the parent Government," and identifies subsistence, lodging and clothing as

61 "Refugees from the Bay of Islands" p 3.

62 "Latest English Intelligence"(20 December 1845) p 165.

63 "Destruction by Fire" (19 December 1846) p 3;

"Destruction by Fire" (23 January 1847) p 3. 
required. ${ }^{64}$ The term "parent Government" reflects the colonial context, Canada being described as "her eldest born colonial offspring." 65 Another fire, on a steamboat, in May 1849 in St Louis, set a fleet of boats alit and resulted in hundreds of families being "rendered homeless and houseless."66

Reportage of the October 1847 Tobago hurricane distinguished buildings and dwelling-houses, noting both of these architectures - if left standing - would be used to accommodate the homeless. ${ }^{67}$ Damage from the 1848 flooding of the Missisippi made "thousands of families ... houseless,"68 but the Wellington earthquake, of that same year made immediate the trauma of natural disaster. Churches, religious properties, friends' wooden houses, and "the bush among the hills," became houseless refuges. ${ }^{69}$ Poor appears to be used to reflect fortunate rather than financial status. In contrast to the English accounting of homelessness,

64 "Destruction by Fire" (19 December 1846) p 3.

65 "Destruction by Fire" (19 December 1846) p 3.

66 "The United States" p 142.

67 "Awful Hurricane at Tobago" p 2; "Miscellaneous" (10 May 1848) p 3.

68 "Latest English Intelligence" (10 June 1848) p 57.

69 "Wellington Extracts" p 145; "Public Meeting" p 4;

"Lieutenant-Governor Eyre's Despatches" p 164. adjectives such as "many" and "numbers of" substituted precise counts of the houseless and homeless. ${ }^{70}$

\section{Conclusion}

Within a few short years New Zealand shifted from being positioned as the answer to England's welfare problems to having an identified group of homeless of its own, which threatened to cause these houseless fugitives to possibly leave the Colony. What, from a twenty-first century perspective, is noteworthy is that homelessness is largely a problem for Pākehā, not Māori, and a consequence of fires, natural disasters and a consequence of the events at Kororäreka in 1845. Equally important is the imported nature of the concept of homelessness.
70 "Public Meeting" p 4; Eyre "Government Gazette" p 3; "Lieutenant-Governor Eyre's Despatches" p 164. 


\section{REFERENCES}

"Architecture Faculty, Students Help Develop Lubbock Homeless Facility" Texas Tech Today (10 October 2014) http://today.ttu.edu/2014/10/architecture-faculty-students-helpdevelop-lubbock-homeless-facility/

"Art and Literature: The Wife" Wellington Independent (23 July 1845): 4.

"Awful Hurricane at Tobago" New Zealander (3 May 1848) p. 2;

"Miscellaneous" New Zealand Spectator and Cook's Strait Guardian (10 May 1848):3.

"The Canadian Ship-Fever: From The Times" New Zealander (8 March 1848): 3.

"Cape of Good Hope: Proclamation issued by Sir H. Smith, Governor of the Cape of Good Hope, to the Settlers beyond the Orange River" New Zealander (22 July 1848) p. 1 (supplement).

Day, Patrick Making of the New Zealand Press: a study of the organizational and political concerns of New Zealand newspaper controllers, 1840-1880 [Wellington]: Victoria University Press, 1990.

"Demography of England" Wikipedia https://en.wikipedia.org/wiki/Demography_of_England

"Destruction by Fire of St. John's New Foundland" Wellington Independent (23 January 1847):3.

"Destruction by Fire of St John's Newfoundland" New Zealander (19 December 1846):3.

Dickens, Charles American Notes for General Circulation London: Chapman \& Hall, October 1842.

"Electricity Applied to Agriculture: Home" New Zealander (1 November 1845): 4.

Ellison, David "Mobile Homes, Fallen Furniture, and the Dickens Cure" South Atlantic Quarterly (Winter 2009) 108(1): 87-114.

"English Extracts: Colonial Office Colonization No. 3" Daily Southern
Cross (6 May 1843): 3.

"English Extracts" Nelson Examiner and New Zealand Chronicle (6 April 1844): 19.

"English Extracts" Nelson Examiner and New Zealand Chronicle (16 September 1848): 115.

"English Intelligence" Wellington Independent (11 September 1847): 3.

Eyre, E. [Govenor in Chief] "Government Gazette" New Zealander (15 November 1848):3.

A father of Half-Caste Children "Original Correspondene [sic]: to the parents of half caste children in New Zealand" New Zealander (9 October 1847): 3.

"Hamilton plan to ban rough sleeping" Radio New Zealand (28 October 2014) http://www.radionz.co.nz/news/regional/257945/hamiltonplan-to-ban-rough-sleeping

Hood, Thomas "The Bridge of Sighs" New Zealander (22 August 1846): 4. "Ireland: State of the West" New Zealander (31 October 1849): 4.

Joplin, Robert Croudace New Zealand: a poem (Auckland: printed by John Moore, 1843)

Kidd, Alan "The "Liberal State": Civil Society and Social Welfare in Nineteenth-Century England" Journal of Historical Sociology (1 March 2002): 114-119.

A land purchaser and farmer "Correspondence" Nelson Examiner and New Zealand Chronicle (6 May 1848): 37.

"Latest English Intelligence" Nelson Examiner and New Zealand Chronicle (15 June 1844): 60.

"Latest English Intelligence" Nelson Examiner and New Zealand Chronicle (20 December 1845):165.

"Latest English Intelligence" Nelson Examiner and New Zealand Chronicle (10 June 1848):57. 
"Latest News" New Zealander (11 September 1847): 3.

"Lieutenant-Governor Eyre's Despatches respecting the late earthquakes at Wellington" Nelson Examiner and New Zealand Chronicle (9

December 1848):164.

Mayor and WCC Staff Temporarily Homeless" (7 October 2014) http://wellington.govt.nz/your-council/news/2014/10/mayor-and-wccstaff-temporarily-homeless

"Miscellaneous" New Zealand Gazetter and Wellington Spectator (8 November 1843): 3.

"Miscellaneous" New Zealand Spectator and Cook's Strait Guardian (19 May 1847): 2.

"Nelson" Wellington Independent (4 September 1847): 2.

"The Nelson Examiner" Nelson Examiner and New Zealand Chronicle (18 November 1843): 354.

"The Nelson Examiner" Nelson Examiner and New Zealand Chronicle (10 May 1845): 38.

"New School [advertisement]" Daily Southern Cross (10 June 1843) p 2.

"New Zealand Gazette and Wellington Spectator" New Zealand Gazette and Wellington Spectator (28 May 1842): 2-3.

"The New Zealander" The New Zealander (13 January 1849): 2.

"Night Asylum for the Houseless " The Glasgow Story (2004) http://www.theglasgowstory.com/image.php?inum=TGSG00034

"Obituary [Ralph Croudace Joplin]" Gouldburn Herald (Wednesday 10 July 1907): 3.

"On Recent Events" Daily Southern Cross (29 March 1845): 2.

Poirer, Donald Charity Law in New Zealand Wellington: Charities Services, June 2013 p 88.

"Population" Statistics NZ http://www3.stats.govt.nz/historic_publications/1871-census/1871results-census.html\#idsect1_1_506
Prickett, Nigel Landscapes of Conflict: a field guide to the New Zealand Wars (Auckland: Random House, 2002)

"Public Meeting" New Zealand Spectator and Cook's Strait Guardian (29 November 1848):4.

"The Rage for Emigration, and the causes of it." Nelson Examiner and New Zealand Chronicle (10 March 1849): 5.

"Re-Emigration" New Zealand Gazette and Wellington Spectator (29 November 1843): 3.

"Refugees from the Bay of Islands" Daily Southern Cross (12 April 1845):3. Rivers, Bryan "'"'Tenderly" and "With care"'": Thomas Hood's "The Bridge of Sighs" and the suicide of Harriet Shelley" Notes and Queries (September 2006) 53(3): 327-329.

S.T. "[Letter to the Editor]" "Correspondence. To the Editor of the Nelson Examiner" Nelson Examiner and New Zealand Chronicle (1 March 1845): 206.

S.T. "To the Editor of the Nelson Examiner" Nelson Examiner and New Zealand Chronicle (15 March 1845): 7.

"Scraps of English News" Nelson Examiner and New Zealand Chronicle (4 September 1847): 106.

Smith, Philippa Mein A Concise History of New Zealand Cambridge: Cambridge University Press, 2005: 44.

A Sub-Tenant (28 June 1844) "To the Editor of the New Zealand Gazette and Wellington Spectator" New Zealand Gazette and Wellington Spectator (10 July 1844): 3.

Subscriber (18 February 1848, Porirua) "Original Correspondence: To the Editor of the "Independent"' Wellington Independent (23 February 1848): 3.

"The United States" Nelson Examiner and New Zealand Chronicle (10 November 1849):142.

University of Oregon "UO architecture students work together to tackle 
homelessness" (6 November 2012) http://aaa.uoregon.edu/news/uoarchitecture-students-work-together-tackle-homelessness

"Wellington Extracts" Nelson Examiner and New Zealand Chronicle (11

November 1848):145.

"Wellington Independent" Wellington Independent (28 May 1845): 2.

Wigley, Mark "Paradise Lost and Found: the Insinuation of Architecture in New Zealand" New Zealand Architect (1986) 5: 44-45. 